\title{
Potencial of energy saving in the fish and seafood cold storage in San Francisco de Campeche
}

\section{Potencial de ahorro energético en cámara de refrigeración de pescados y mariscos en San Francisco de Campeche}

TEC-ACEVEDO, Francisco $\dagger^{*}$, HUCHIN-MISS, Mauricio, DEMESA-LÓPEZ, Francisco and OVANDO-SIERRA, Juan

Universidad Autónoma de Campeche, Faculty of Engineering

ID $1^{\text {st }}$ Author: Francisco, Tec-Acevedo / ORC ID: 0000-0002-6344-7761, CVU CONACYT ID: 1062275

ID $1^{\text {st }}$ Co-author: Mauricio, Huchin-Miss / ORC ID: 0000-0002-5669-9098, Researcher ID Thomson: S-2354-2018, CVU CONACYT ID 917567

ID $2^{\text {nd }}$ Co-author: Francisco, Demesa-López / ORC ID: 0000-0001-7197-6017, Researcher ID Thomson: ANN-56062021, CVU CONACYT ID 351561

ID $3^{\text {rd }}$ Co-author: Juan, Ovando-Sierra / ORC ID: 0000-0003-4358-6657, Researcher ID Thomson: S-2357-2018, CVU CONACYT ID: 358434

DOI: $10.35429 /$ JTIP.2021.12.5.24.32

Received March 30, 2021; Accepted June 30, 2021

\begin{abstract}
The following paper focuses on energy efficiency applied to a company dedicated to the conservation and freezing of seafood products located in the city of San Francisco de Campeche, Camp, Mexico. For this, a theoretical study is carried out to determine the energy saving potential of one of the refrigeration systems currently installed in the company to fulfill the hypothesis of obtaining savings of up to $3 \%$ in energy consumption by reducing $1{ }^{\circ} \mathrm{C}$ the condensing temperature of the system. The main thermal loads of the system are Mayan octopus, shrimp, and fish (various). With the help of the Genetron Properties Software, the different calculations are carried out by making variations in the condensation and conservation temperatures, without varying the thermal load, but considering a correct and incorrect heat exchange of the condensing units with the outside.
\end{abstract}

Energy efficiency, Refrigeration, Energy saving

\begin{abstract}
Resumen
El siguiente artículo se centra en la eficiencia energética aplicada a una empresa dedicada a la conservación y congelación de productos del mar ubicada en la ciudad de San Francisco de Campeche, Camp, México. Para ello se realiza un estudio teórico para determinar el potencial de ahorro energético de uno de los sistemas de refrigeración actualmente instalado en la empresa con la finalidad de cumplir la hipótesis de obtener un ahorro de hasta un $3 \%$ de ahorro en consumo energético al disminuir $1{ }^{\circ} \mathrm{C}$ la temperatura de condensación del sistema. Las principales cargas térmicas del sistema son: pulpo maya, camarón y pescados (varios). Con ayuda del Software Genetron Properties se realizan los diferentes cálculos realizando variaciones en las temperaturas de condensación y conservación sin variar la carga térmica, pero considerando un correcto e incorrecto intercambio de calor de las unidades condensadoras con el medio.
\end{abstract}

Eficiencia energética, Refrigeración, Ahorro energético

Citation: TEC-ACEVEDO, Francisco, HUCHIN-MISS, Mauricio, DEMESA-LÓPEZ, Francisco and OVANDO-SIERRA, Juan. Potencial of energy saving in the fish and seafood cold storage in San Francisco de Campeche. Journal of Technologies in Industrial Processes. 2021. 5-12: 24-32

\footnotetext{
* Author Correspondence (al043991@ uacam.mx)

$\dagger$ Researcher contributing as first author.
} 


\section{Introduction}

Energy efficiency in refrigeration for conservation or freezing products is an issue that has gained relevance in recent years given the great energy demand of the equipment to get the appropriate temperatures on the different products. The main benefit is reflected in the savings that are getting without sacrificing the quality of the final product.

In this paper, two cases of the energy behavior of fish and seafood in a conservation room with a condensing unit model MDBX1000M6C installed in the city of San Francisco de Campeche are studied.

For case A, the energy behavior is evaluated with an ambient temperature in a range of $30^{\circ} \mathrm{C}$ to $40^{\circ} \mathrm{C}$ and heat exchange between the outside and the condensing unit.

For case B, the energy behavior is evaluated with an ambient temperature in a range of $30{ }^{\circ} \mathrm{C}$ to $40{ }^{\circ} \mathrm{C}$ but with inadequate heat exchange between the outside and the condensing unit (this case is currently presented in the company).

Seafood products are perishable foods, so their quality must be guaranteed especially when implementing energy efficiency measures. It's essential to comply with regulations such as NOM-242-SSA1-2009 that indicates the conditions of the conservation (fresh, refrigerated, frozen, and processed).

Another option is to maintain the organoleptic quality depending on the temperature of refrigeration or freezing. Generally, the optimal refrigeration temperature ranges are from 0 to $4{ }^{\circ} \mathrm{C}$, however, freezing maintains the organoleptic characteristics from temperatures in the center of the fish, from 0 to $5{ }^{\circ} \mathrm{C}$ reached in less than two hours and its subsequent decrease to $-18^{\circ} \mathrm{C}$ (Santana, 2014).

The objective of the work consisted of estimating the potential for energy and economic savings by varying the condensation and evaporation temperatures assuming that the decrease of each degree Celsius generates up to $3 \%$ of electrical energy savings. As will be seen in the methodology section, savings were determined by varying temperatures under climatic and operating conditions. The work includes the following sections:

1. Generalities. In this section, the status of the company's energy consumption is mentioned.

2. Variables that impact the energy consumption of refrigeration systems. The variables that impact the energy consumption of the refrigeration system are mentioned.

3. Caso study. It covers the current state of the company, the dimensions of the refrigeration space, as well as the main thermal loads for the refrigeration processes.

4. Methodology. It contains the information evaluated step by step of the case study.

5. Results. Analyze the results obtained based on the graphs in the previous section.

6. Economic implications. This section presents the economic estimates when evaluating cases $\mathrm{A}$ and $\mathrm{B}$.

7. Conclusions. Includes the main inferences from sections 5 and 6.

\section{Generalities}

The company under study is dedicated to the capture, processing, and commercialization of seafood and is in the city of San Francisco de Campeche, Camp., Mexico.

\begin{tabular}{|l|r|r|r|r|r|}
\hline Tecnology & \multicolumn{1}{c|}{$\begin{array}{c}\text { Installed } \\
\text { Power } \\
\text { kW }\end{array}$} & \% & \multicolumn{1}{c|}{$\begin{array}{c}\text { Monthly } \\
\text { Consumption } \\
\text { (kWh/month) }\end{array}$} & \multicolumn{2}{c|}{$\begin{array}{c}\text { Anual } \\
\text { Consumption } \\
\text { (kWh/year) }\end{array}$} \\
\hline Lighting & 5.73 & 4.9 & $1,598.58$ & 3.9 & $19,182.93$ \\
\hline Air conditioner & 8.11 & 6.9 & $2,028.12$ & 4.9 & $24,337.4$ \\
\hline Miscellaneous & 7.55 & 6.4 & 39.25 & 0.1 & 471 \\
\hline Refrigeration & 88.37 & 75.3 & $36,760.26$ & 89.2 & $441,123.12$ \\
\hline $\begin{array}{l}\text { Motors and } \\
\text { pumps }\end{array}$ & 7.63 & 6.5 & 771.06 & 1.9 & $9,252.72$ \\
\hline Total & 117.4 & 100 & 41,197 & 100 & 494,364 \\
\hline
\end{tabular}

Table 1 Total energy consumption Source: Own Elaboration

Of the total electricity consumption, $89 \%$ belongs to the consumption of refrigeration equipment as shown in Table 1 ( 2 cold rooms for freezing and 2 more for conservation). This work focuses only on one of the conservation rooms that operates with a condensing unit model MDBX1000M6C with R404A refrigerant.

\section{Variables that impact the energy consumption of refrigeration systems}

The improvement options that were proposed are the following: 


\subsection{Reduction of evaporation temperature in refrigeration systems}

According to the Mexican Standard NOM-242SSA1-2009, the temperature of the fishing products corresponds to those shown in Table 2.

\begin{tabular}{|l|l|}
\hline Cold room type & Temperature \\
\hline Conservation & 0 to $4{ }^{\circ} \mathrm{C}$ \\
\hline Freezing & 0 to $-18^{\circ} \mathrm{C}$ \\
\hline
\end{tabular}

Table 2 Fish product temperature Source: Own Elaboration

Achieving and maintaining these thermal levels in the product implies a high consumption of electrical energy for the production of cold in the storage rooms and these consumptions are directly related to the evaporation and condensation temperatures, therefore, the variation of these temperatures results determining factor in the cooling capacity from the thermodynamic approach. Therefore, it is essential to evaluate the relationship of these operating parameters through a detailed analysis. Figure 1 shows the behavior of the cooling capacity $(\mathrm{Qe})$ at different thermal levels of evaporation and condensation for different refrigerants.

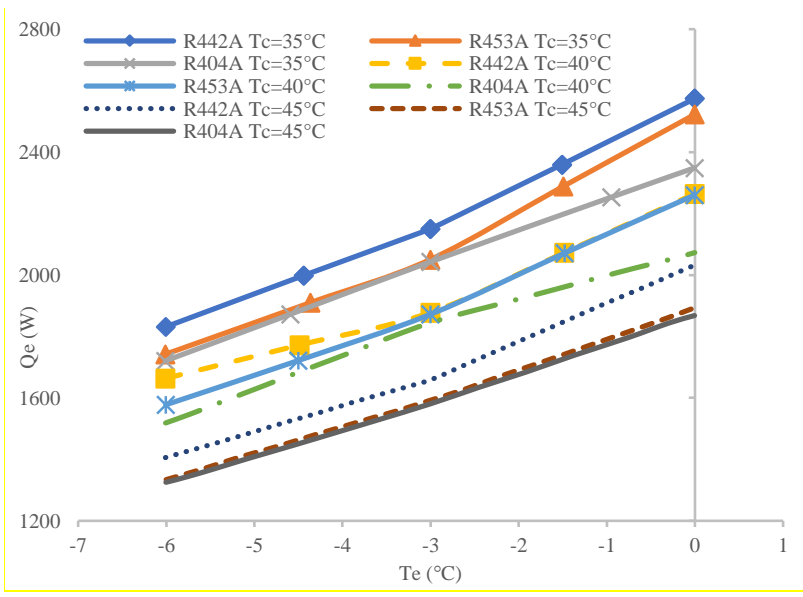

Figure 1 Variation of cooling capacity for different evaporation temperatures in different refrigerants Source: Oruc, V. et al 2017

If we observe the behavior of R404A, it is noted that the lower the evaporation temperature (Te) and the higher the condensation temperature $(\mathrm{Tc})$, the cooling capacity (Qe) decreases, so it is assumed that reducing the evaporation temperature to maintain the product temperature in a cold room hurts the refrigeration capacity. In contrast, a reduction in the condensing temperature improves the potential for heat extraction in the evaporator.

To reduce the condensation temperature, pay attention to the temperature of the outside (heat sink) because the condensation temperature will increase or decrease depending on the variation in ambient temperature, but also on the heat transfer capacity and the condenser transfer area. The connection between the compressor's energy consumption (We) and the evaporation temperature is shown in Figure 2. The pressure change between the evaporator outlet and the condenser inlet is obtained from the addition of mechanical energy in the compressor (We), ideally through an isentropic process. This energy exchange is proportional to the initial and final state of the refrigerant, depending on the thermal levels because $P=f$ (Tsat). The increase or decrease in energy consumption is proportional to the increase or decrease in evaporation temperature when the condensation temperature is constant.

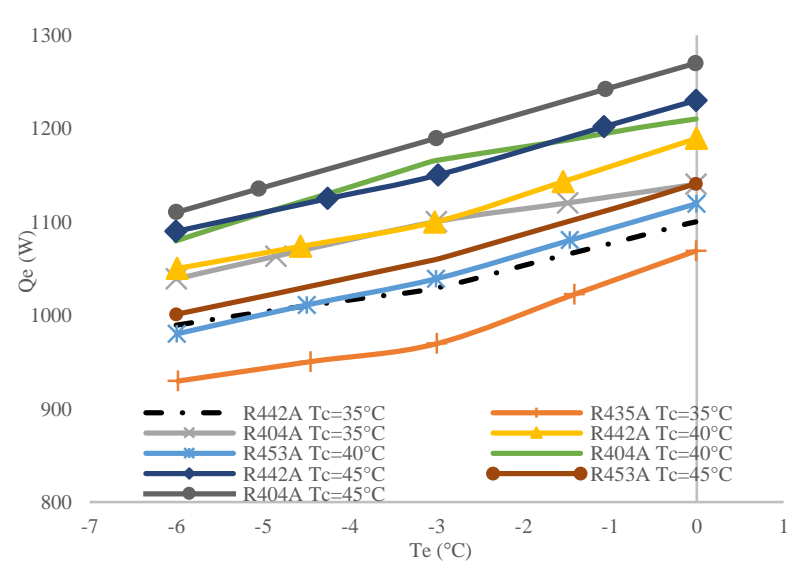

Figure 2 Energy consumption for different evaporation temperatures in different refrigerants Source: Oruc, V. et al 2017

For the case of R404A, it is shown that a decrease of $6^{\circ} \mathrm{C}$ in the evaporation temperature $\left(\mathrm{Tc}=45^{\circ} \mathrm{C}\right)$, the energy consumption of the compressor decreases by $12.8 \%$ (from 1275 to 1112 Watts). This behavior is maintained for the variation of the condensation temperature, for example, when $\mathrm{Tc}$ decreases $5{ }^{\circ} \mathrm{C}\left(\mathrm{Te}=-6^{\circ} \mathrm{C}\right)$ there is a decrease in energy consumption of $3.7 \%$ (from 1080 to 1040 Watts).

\subsection{Reduction of condensation temperature in refrigeration systems}

In a study of alternative refrigerants to R404A (Calleja, 2018), the effect of condensation temperature $(\mathrm{Tc})$ on volumetric capacity, the COP, the quality of steam at the evaporator inlet, and discharge temperature (Td) of different refrigerants was evaluated. 
The analysis was carried out for $\mathrm{Te}=-10$ ${ }^{\circ} \mathrm{C}, \mathrm{Tc}=25^{\circ} \mathrm{C}$ to $45^{\circ} \mathrm{C}$, isentropic efficiencies from 0.7 to 1 , and a volumetric efficiency of $100 \%$ of the compressor. The results showed that the COP reaches values higher than 3 at a Tc of $45^{\circ} \mathrm{C}$ and as the condensation temperature decreases to $25^{\circ} \mathrm{C}$, the COP increases to around $6 \%$. Lowering the condensing temperature decreases the energy supplied to the compressor, increasing the COP.

The condenser is the component responsible for dissipating the latent heat absorbed by the refrigerant in the evaporator to the heat sink. This energy is released by forced convection to a cooling medium, generally air at environment temperature. The physical arrangement of this component can limit or block the forced circulation of air or accumulate thermal energy, affecting the performance of the condenser and consequently the cooling system. Saidur et al., (2002) found that for each degree centigrade increase in ambient temperature, the energy consumption of the refrigeration system increased by $4 \%$. This percentage may be higher if the condensers are installed in a limited space, which will consequently increase the temperature of the surroundings and the Tc of the equipment.

\section{Case study}

The cold room is an insulated enclosure of $6 \times 4.5 \times 3.5 \mathrm{~m}$ with $50 \mathrm{~mm}$ thick expanded polyurethane (polyurethane foam). It has a maximum capacity of 5 tons to contain various kinds of fish and seafood. The condensing unit MBDX1000M6C model uses a Copeland discus compressor of the semi-hermetic alternative type of cylinders. It works with R404A refrigerant at a voltage of $230 \mathrm{~V} / 3 \mathrm{~F} / 60 \mathrm{HZ}$, of $10 \mathrm{HP}$ capacity for outdoor operation with a draft of horizontal air. In addition to the temperature conditions in Campeche, the main problem is the concentration of 6 condensing units in a limited space, so that arrangement of the units limit heats dissipation and consequently blocks airflow, so there is an increase in the ambient temperature that reduces the heat transfer rate towards the environment and increase the condensation temperature.

For analysis purposes, an increase in the ambient temperature value of $1.5{ }^{\circ} \mathrm{C}$ was considered, due to the concentration of condensers in space.
In Table 3, an annual summary of the thermal loading conditions in the company is observed, for the desired product (shrimp, octopus, fresh fish) temperature of $-13{ }^{\circ} \mathrm{C}$, which consider the product entering at ambient temperature and the one that is kept at optimum temperature during the harvest and closed season. The desired product temperature was taken from the information provided by the company.

\begin{tabular}{|l|r|r|}
\hline \multicolumn{1}{|c}{ Month } & \multicolumn{1}{c|}{$\begin{array}{c}\text { Thermal load } \\
\text { (BTU/h) }\end{array}$} & $\begin{array}{c}\text { Tons of } \\
\text { product/month }\end{array}$ \\
\hline January & $72,754.77$ & 4.5 \\
\hline February & $67,456.07$ & 4 \\
\hline March & $64,243.73$ & 6.5 \\
\hline April & $72,754.77$ & 4.5 \\
\hline May & $76,542.45$ & 5 \\
\hline June & $75,455.54$ & 5 \\
\hline July & $75,455.54$ & 5 \\
\hline August & $77,085.91$ & 5 \\
\hline September & $71,787.21$ & 4.5 \\
\hline October & $71,515.49$ & 4.5 \\
\hline November & $71,068.28$ & 5 \\
\hline December & $71,068.28$ & 5 \\
\hline
\end{tabular}

Table 3 Thermal load for different months of operation of the company

Source: Own Elaboration

\section{Methodology}

To quantify the energy improvement obtained to reduce the evaporation and condensation temperature, it's necessary to evaluate the COP, cooling power $\left(P_{e}\right)$, and the compressor power $\left(P_{c}\right)$ under operating conditions with the R404A refrigerant and that it depends on the mechanical and electrical performance. When looking the Figure 3, it's established that the before mentioned parameters are defined as a function of their enthalpies, so:

$C O P=\frac{h_{7}-h_{6}}{h_{2}-h_{1}}$

Thermal load $=\dot{m}\left(h_{7}-h_{6}\right)$

mass flow $=\dot{m}=\frac{P_{e}}{h_{7}-h_{6}}$

Compressor Power $=P_{c}=\frac{\dot{m}\left(h_{2}-h_{1}\right)}{n_{m} * n_{e}}$ 


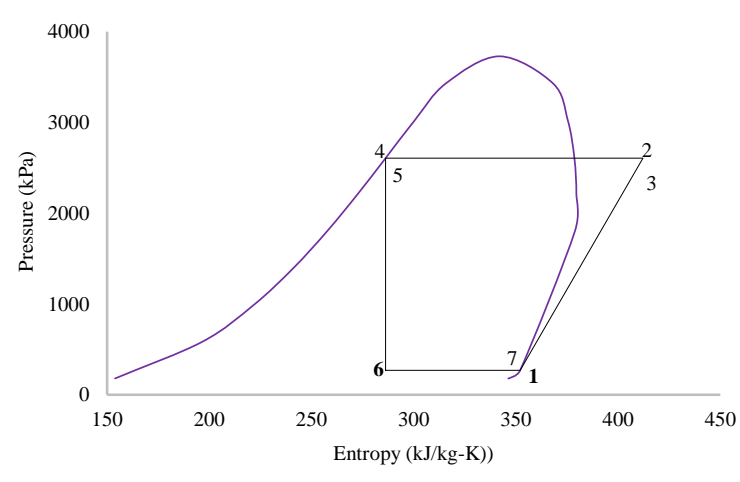

Figure 3 Refrigeration cycle of the case study Source (own elaboration with Genetron Properties Software)

In the following calculations, an initial evaporation temperature of $-23{ }^{\circ} \mathrm{C}$ to $-20{ }^{\circ} \mathrm{C}$ was considered. Also, it was considered condensation temperature related to ambient temperatures in a range of $30{ }^{\circ} \mathrm{C}$ to $40{ }^{\circ} \mathrm{C}$ for months of the summer and off summer. This Interval corresponds to the average maximum average temperature of the 2015-2018 period prevailing in the entity and reported by the Campeche observatory Campeche of the Comisión Nacional del Agua (CONAGUA). Graph 1 shows the months February to September and Graph 2 the months of March to August.

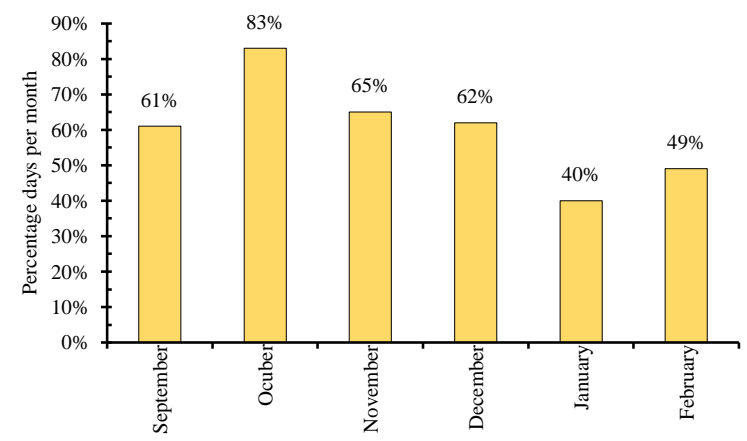

Graph 1 Percentage of days per month with temperatures $\geq 30{ }^{\circ} \mathrm{C}$ and $<35^{\circ} \mathrm{C}, 2015-2018$

Source: Own Elaboration

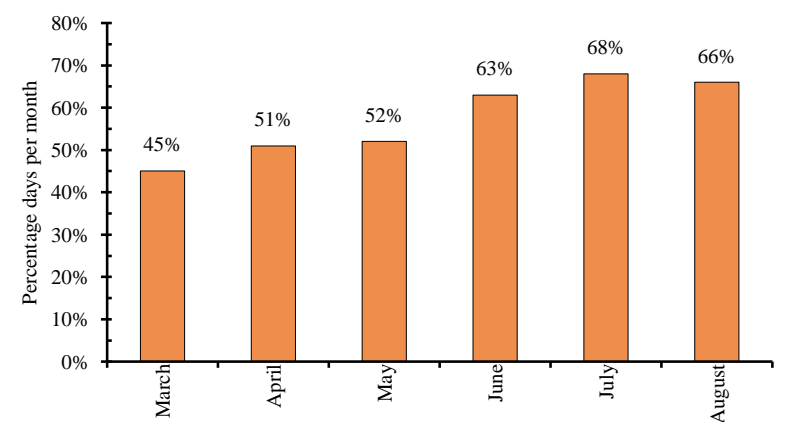

Graph 2 Percentage of days per month with temperatures $\geq 35^{\circ} \mathrm{C}$ and $<40{ }^{\circ} \mathrm{C}, 2015-2018$

Source: Own Elaboration
With this information, we proceeded to analyze the operating parameters of the refrigeration system considering two cases:

A. Energy behavior of the system for a correct distribution of the condensing units.

B. Energy behavior of the system for an inadequate distribution of condensing units (current situation).

Graphs 3 and 4 show the variation of the compressor power in $\mathrm{kW}$ for January in cases A y B.

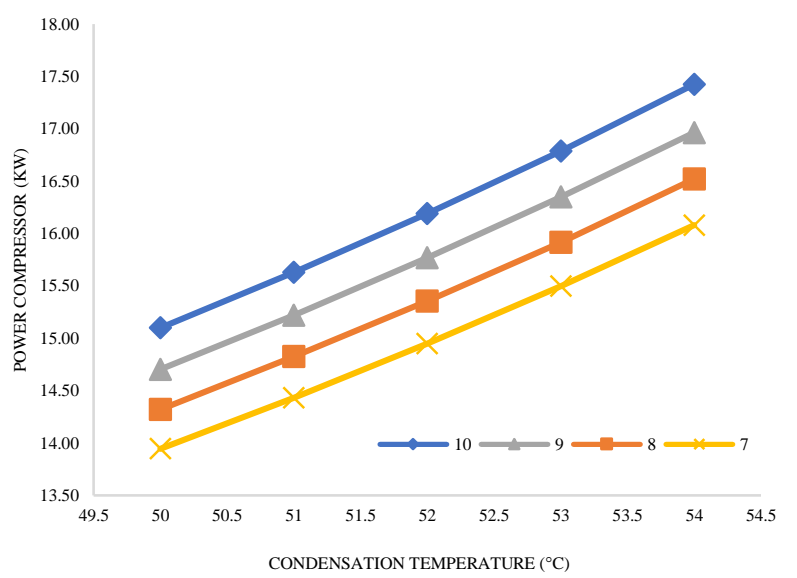

Graph 3 Compressor power at different condensing temperatures in January case A

Source: Own Elaboration

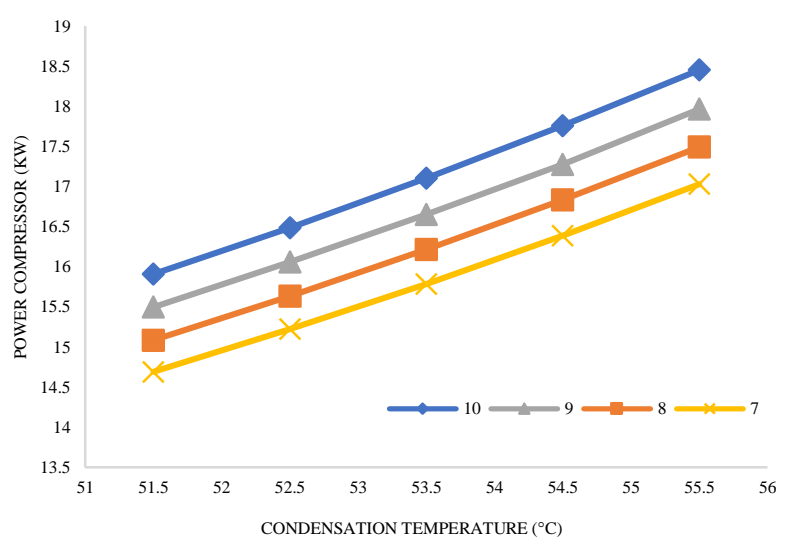

Graph 4 Compressor power at different condensing temperatures in January case B

Source: Own Elaboration

On the other hand, Graphs 5 and 6 present the variation of the COP in January in the cases A y B. 


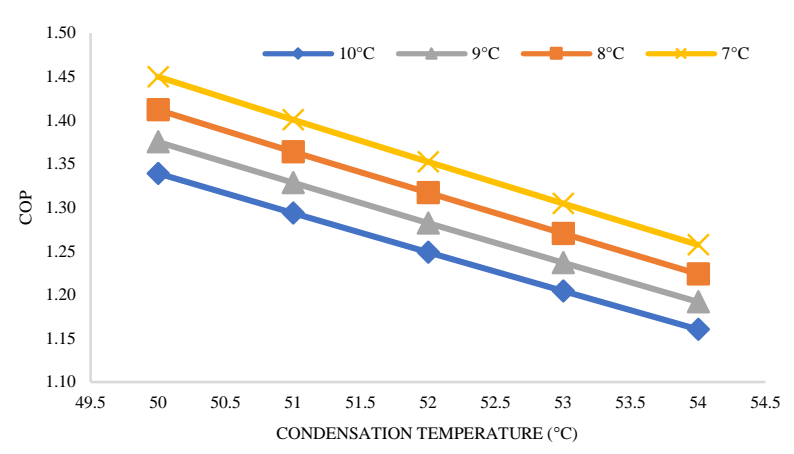

Graph 5 COP at different condensation and evaporation temperatures in January case A

Source: Own Elaboration

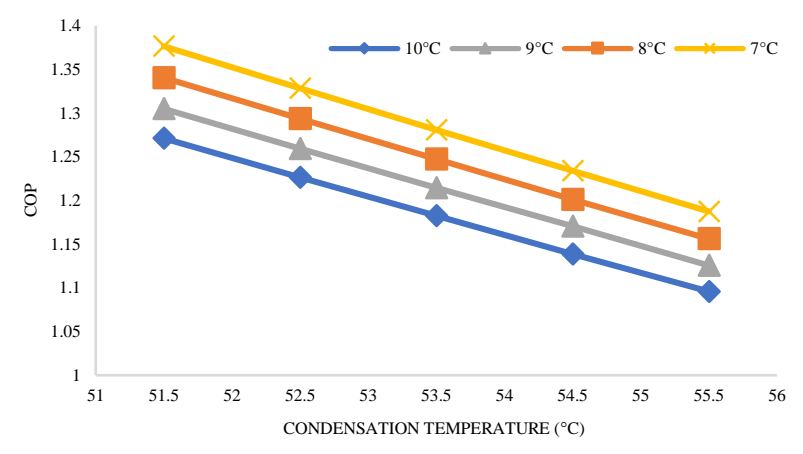

Graph 6 COP at different condensation and evaporation temperatures in January case B

Source: Own Elaboration

Graphs 7 and 8 show the variation of the compressor power in $\mathrm{kW}$ in March in cases $\mathrm{A}$ and $\mathrm{B}$.

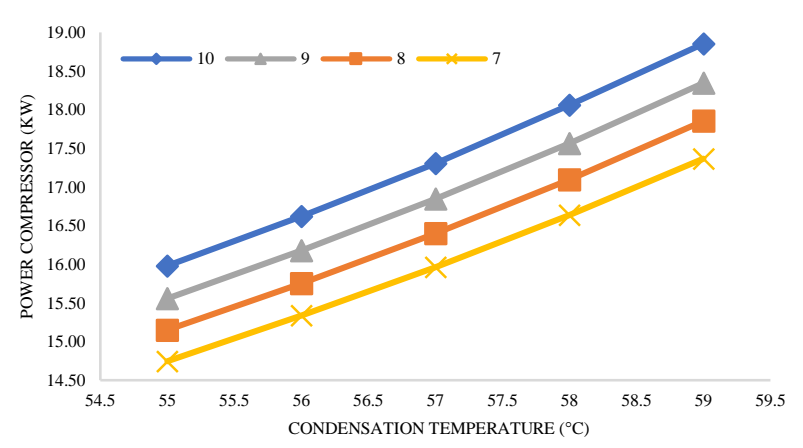

Graph 7 Compressor power at different condensation temperatures in March case A

Source: Own Elaboration

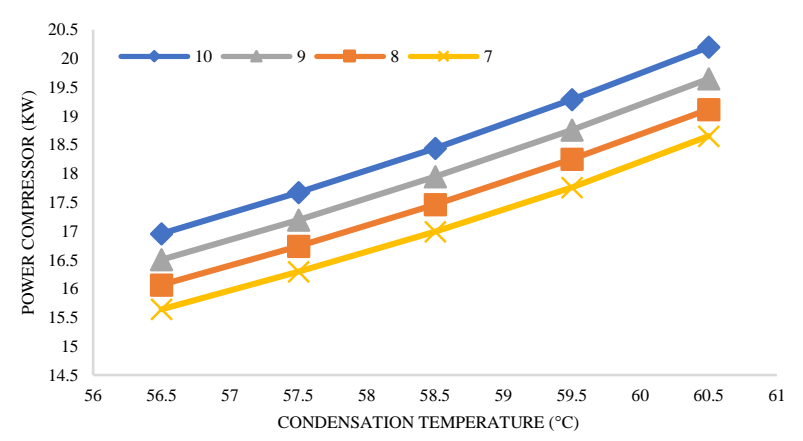

Graph 8 Compressor power at different condensation temperatures in March case B

Source: Own Elaboration

ISSN 2523-6822

ECORFAN® All rights reserved
Graphs 9 and 10 show the COP variation in March in cases A and B.

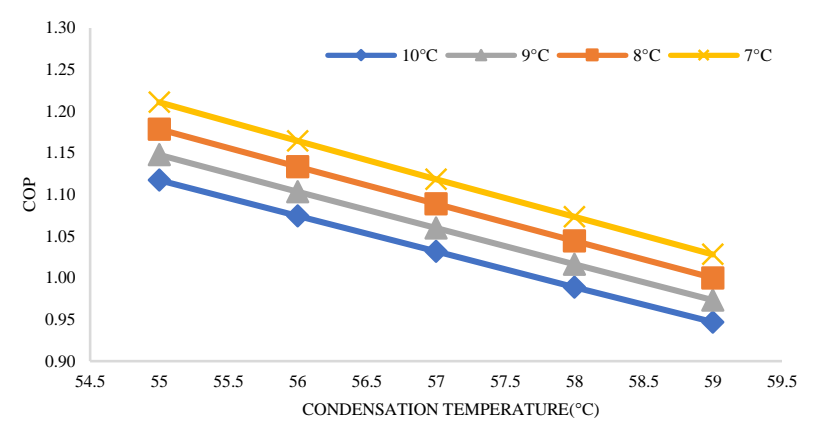

Graph $9 \mathrm{COP}$ at different condensation and evaporation temperatures in March case A Source: Own Elaboration

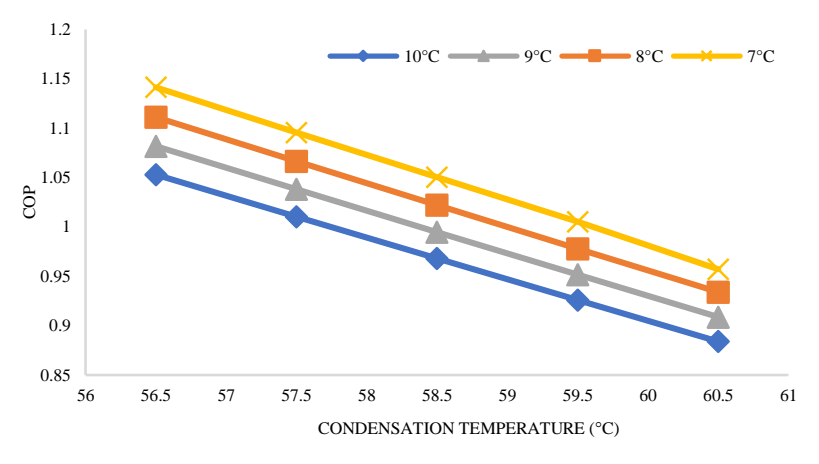

Graph $10 \mathrm{COP}$ at different condensation and evaporating temperatures in March case B

Source: Own Elaboration

Graphs 11 and 12 show the behavior of energy consumption in case A.

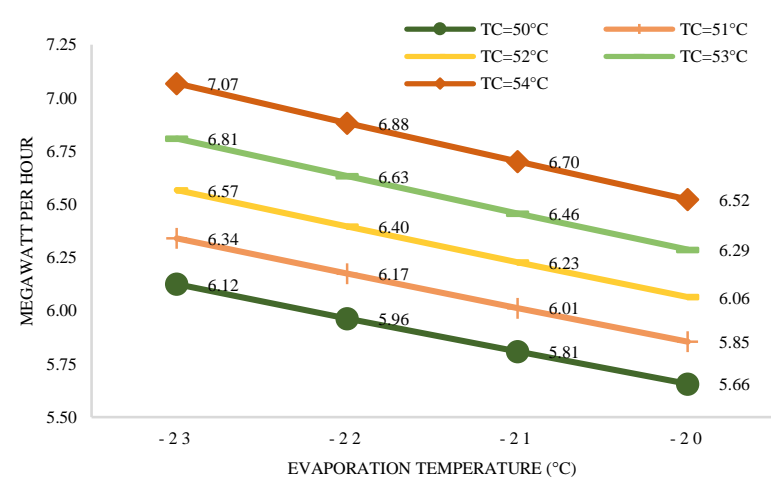

Graph 11 Behavior of energy consumption without increases in ambient temperature from September to January case A

Source: Own Elaboration 


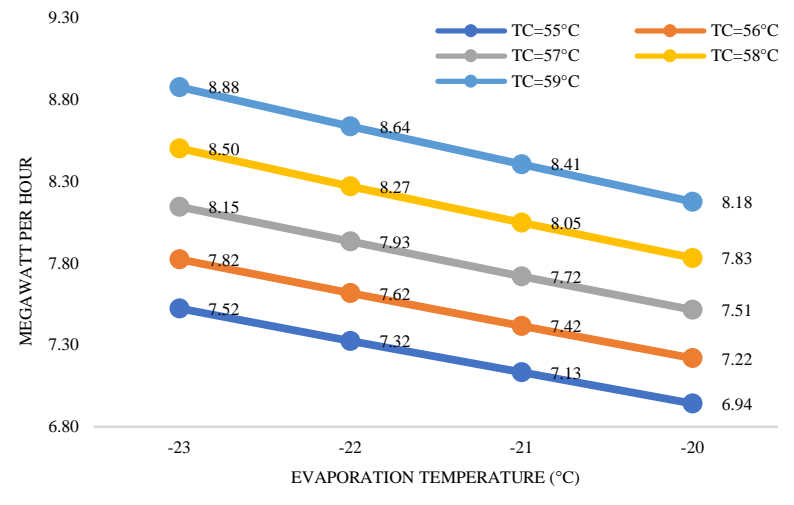

Graph 12 Behavior of energy consumption without increases in ambient temperature from March to August case A

Source: Own Elaboration

Graphs 13 and 14 show the behavior of energy consumption in case B

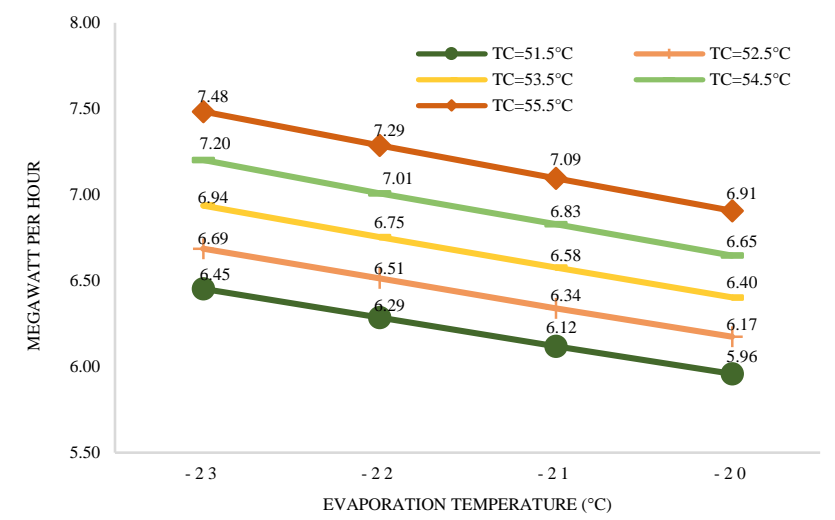

Graph 13 Behavior of energy consumption with an increase of up to $1.5^{\circ} \mathrm{C}$ in ambient temperature from September to January case B

Source: Own Elaboration

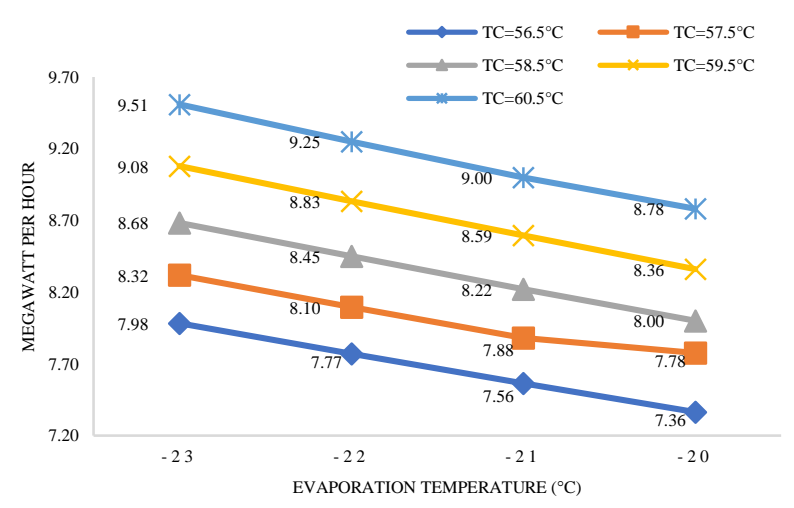

Graph 14 Behavior of energy consumption with an increase of up to $1.5{ }^{\circ} \mathrm{C}$ in ambient temperature from March to August case B

Source: Own Elaboration

\section{Results}

The results obtained were carried out with the support of the Genetron Properties Software considering a volumetric and isentropic efficiency of 0.75 . Two cases were evaluated:
A. Energy behavior of the system under the operating conditions of table 3 and ambient temperatures from $30{ }^{\circ} \mathrm{C}$ to 40 ${ }^{\circ} \mathrm{C}$ for a correct distribution of the condensing units.

B. Energy behavior of the system under the operating conditions of table 3 and ambient temperatures from $30{ }^{\circ} \mathrm{C}$ to 40 ${ }^{\circ} \mathrm{C}$ for an inadequate distribution of the condensing units (current situation).

From Graphs 3 and 4, it's observed that there is an increase of $2.7 \%$ of the power compressor for each degree centigrade that evaporation temperature increases. While there is an approximate $3.6 \%$ increase in compressor power for each degree that the condensing temperature increase.

Graphs 5 and 6 show a decrease of $2.9 \%$ and $3.5 \%$ of the COP for each degree centigrade that the evaporation temperature increases and for each degree centigrade that the condensing temperature increases respectively.

Graphs 7 and 8 show the behavior of the compressor power when the condensation and evaporation temperatures vary. The results indicated an increase in compressor power of approximately $4 \%$ for each degree of increase in condensing temperature and an increase greater than $2 \%$ for each degree of increase in evaporation temperature.

Graphs 9 and 10 evaluate the COP of the system when varying the condensation and evaporation temperatures. For both cases, there is an average decrease of $4 \%$ of the COP for each degree that the condensation temperature increases and there is a decrease of $2.7 \%$ for each degree that the evaporation temperature increases.

Graphs 11 and 12 show the behavior of energy consumption for both groups of temperatures assuming a correct distribution of the condensing units. Graphs 13 and 14 show the consumption due to inadequate distribution of the condensing units. In both cases, a decrease of $2 \%$ of the consumption is observed for each degree Celsius that the evaporating temperature is reduced. 


\section{Economic implications}

To determinate the economic savings, the Comisión Nacional de Electricidad (CFE) billings for the 2019 period were used as reference values. With this information, the energy costs per month were estimated considering taxes.

Tables 4 and 5 show the estimate of the monthly economic saving obtained by comparing the energy consumption for cases A and $\mathrm{B}$. The results obtained reflect the impact that occurs when the condenser unit is improperly installed, causing an increase in the surrounding ambient temperature.

\begin{tabular}{|c|c|c|c|c|c|}
\hline \multirow[t]{3}{*}{$\operatorname{Tc}\left({ }^{\circ} \mathbf{C}\right)$} & \multirow{3}{*}{$\begin{aligned} \geq & 30{ }^{\circ} \mathrm{C} \text { at } \\
& <35{ }^{\circ} \mathrm{C}\end{aligned}$} & \multicolumn{4}{|c|}{$\operatorname{Te}\left({ }^{\circ} \mathbf{C}\right)$} \\
\hline & & -23 & -22 & -21 & -23 \\
\hline & & \multicolumn{4}{|c|}{ Save money mnx/month } \\
\hline $50-51.5$ & SEP-FEB & $\$ 1,107$ & $\$ 1,085$ & $\$ 1,182$ & $\$ 1,020$ \\
\hline $51-52.5$ & SEP-FEB & $\$ 1,169$ & $\$ 1,145$ & $\$ 1,103$ & $\$ 1,080$ \\
\hline $52-53.5$ & SEP-FEB & $\$ 1,248$ & $\$ 1,208$ & $\$ 1,175$ & $\$ 1,144$ \\
\hline $53-54.5$ & SEP-FEB & $\$ 1,328$ & $\$ 1,266$ & $\$ 1,256$ & $\$ 1,211$ \\
\hline $54-55.5$ & SEP-FEB & $\$ 1,404$ & $\$ 1,368$ & $\$ 1,326$ & $\$ 1,297$ \\
\hline
\end{tabular}

Table 4 Saving estimates for months with ambient temperatures $\geq 30{ }^{\circ} \mathrm{C}$ and $<35^{\circ} \mathrm{C}$

Source: Own Elaboration

\begin{tabular}{|c|c|c|c|c|c|}
\hline \multirow[t]{2}{*}{$\operatorname{Tc}\left({ }^{\circ} \mathbf{C}\right)$} & $\geq 35^{\circ} \mathrm{C}$ at & \multicolumn{4}{|c|}{$\operatorname{Te}\left({ }^{\circ} \mathbf{C}\right)$} \\
\hline & $<40^{\circ} \mathrm{C}$ & -23 & -22 & -21 & -23 \\
\hline & \multicolumn{5}{|c|}{ Save money mnx/month } \\
\hline $55-56.5$ & MAR-AUG & $\$ 1,558$ & $\$ 1,513$ & $\$ 1,466$ & $\$ 1,432$ \\
\hline $56-57.5$ & MAR-AUG & $\$ 1,680$ & $\$ 1,626$ & $\$ 1,578$ & $\$ 1,533$ \\
\hline $57-58.5$ & MAR-AUG & $\$ 1,820$ & $\$ 1,757$ & $\$ 1,704$ & $\$ 1,649$ \\
\hline $58-59.5$ & MAR-AUG & $\$ 1,957$ & $\$ 1,910$ & $\$ 1,856$ & $\$ 1,790$ \\
\hline $59-60.5$ & MAR-AUG & $\$ 2,147$ & $\$ 2,078$ & $\$ 2,014$ & $\$ 2,055$ \\
\hline
\end{tabular}

Table 5 Saving estimates for months with ambient temperatures $\geq 35^{\circ} \mathrm{C}$ and $<40{ }^{\circ} \mathrm{C}$

Source: Own Elaboration

\section{Conclusions}

From de results obtained in the case study, it is concluded that:

1. Decreasing the condensation temperature of the system by one degree Celsius will reduce electrical energy consumption by up to $3 \%$ and there will be an increase of to $4 \%$ del COP.

2. There is an increase of more than $5 \%$ in energy consumption for the first group of months $\left(\geq 30{ }^{\circ} \mathrm{C}\right.$ and $\left.<35{ }^{\circ} \mathrm{C}\right)$ due to inadequate distribution of condensing units. While in the second group $\left(\geq 35^{\circ} \mathrm{C}\right.$ and $<40{ }^{\circ} \mathrm{C}$ ) the increase is greater than $6 \%$ on average.
3. The results when varying the condensation and evaporation temperatures indicated an increase in the energy consumption of the compressor for each degree centigrade that both temperatures increased with average values of $4 \%$ and $2.7 \%$ respectively.

4. If the condensation temperature increases to $1.5^{\circ} \mathrm{C}$, the theoretical results show an increase of up to $6 \%$ in electrical energy consumption during the months with higher temperatures.

5. Despite only obtaining an economic saving of $1 \%$, it's advisable to maintain a correct distribution of the condensing units to make the most of it. The economic saving of $1 \%$ of the billing only considers a cold room of the four that operate in the company.

\section{References}

Bohn. (2019). Unidades condensadoras 3-50 HP: Recuperado de https://www.bohn.com.mx/ArchivosPDF/BCT062-UCCD-1-Unidades-condensadorasMBDX.pdf

Calleja, D. (2018). Estudios de refrigerantes alternativos al R404A para aplicaciones de refrigeración comercial. (Tesis de pregrado). Escuela Superior de Tecnologías y Ciencias Experimentales. España.

CONAGUA. (diciembre 2020). Resúmenes mensuales de temperaturas y lluvias. (conagua.gob.mx).

Genetron Properties (versión 1.4). Honeywell.

Norma Oficial Mexicana. NOM-242-SSA12009. Productos y servicios. Productos de la pesca frescos, refrigerados, congelados $\mathrm{y}$ procesados. Especificaciones sanitarias y métodos de prueba.

Oruç, V., Devecioğlu, A. G., y Ender, S. (2017). Improvement of energy parameters using $\mathrm{R} 442 \mathrm{~A}$ and $\mathrm{R} 453 \mathrm{~A}$ in a refrigeration system operating with R404A. Applied Thermal Engineering, 129, 243-249. doi: https://doi.org/10.1016/j.applthermaleng.2017.1 0.035 . 
Saidur, R., Masjuki, H., y Choundhury, J. (2002). Role of ambient temperature, door opening, thermostat setting position and their combined effect on refrigerator-freezer energy consumption. Energy Conversion and Management, 43(6), 845-854. doi: https://doi.org/10.1016/S0196-8904(01)000693.

Santana, I. (2014). UF1224: Elaboración de conservas de pescados y mariscos. España: IC Editorial. 